\title{
From the Great Depression to the Great Recession
}

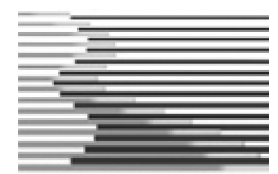

The 1932 Hayek-Keynes Debate: A Study in Economic Uncertainty, Contingency, and Criticism

\section{David B. Hingstman}

Dept. of Communication Studies, University of Iowa, Iowa City, IA USA

\section{G. Thomas Goodnight}

Annenberg School for Communication, University of Southern

California, Los Angeles, CA USA

Poroi, 7,1 (January 2011)

Rhetoric enters into economics frequently at the junctures of alternative government policies and debates grounding competing theories of unexpected events and prudent solutions. When economies turn in widely unanticipated directions, critical discussions arise to spark questions about the legitimacy, power, and correctness of policy response.

In October 1932, there appeared in The Times of London a series of brief letter exchanges signed by John Maynard Keynes and Friedrich August von Hayek (along with some of their associates) in which alternative explanations were defended about the causes of economic activity. Those explanations were grounded in macro- and microeconomics, which in the terms of the 1930 s were contested as trade cycle or monetary theories (Rizzo, 2009). Also at issue, however, was a choice between alternative strategies of political economy. Nineteen thirty-two appeared to be a time of nascent recovery from the effects of falling equity values, but also could be seen as the beginning of a new era of trade protectionism and monetary contraction. One policy choice was for governments to distribute tax or printed money to citizens in the form of unemployment insurance or guaranteed employment programs to supplement private spending. Another was for governments to exercise restraint in borrowing and spending and let private capital adjust economies to new productive levels by securing good investments over time. While the subsequent decisions of the British government conformed to neither choice unequivocally, the events of the Great Depression that followed have at various times been appropriated by Hayek and Keynes' successors as evidence that the theoretical arguments of one or other have been vindicated by collective experience.

The present day is another time in which theoretical controversy and alternative practices are conjoined. Named by some as "the Great Recession," the period that began in 2008 has seen accelerating rates of defaults on loan repayments, job layoffs, financial institutional distress, and speculative shortselling of sovereign debt. But this moment has also 
been articulated as the initiation of a new process of recovery. "The news media are singularly lacking in any explanation for the recent resurgence of the world economy beyond the improvement in leading indicators, such as stock market prices and retail sales numbers" (Akerlof \& Shiller, 2010, vii).

Conflicting appearances spark economic uncertainty, and when security falls, a boom time for economic debates flourishes. Contestation over the relation between theory, policy and practice articulate different, competing ways of envisioning ideal relationships among economics, markets, and state intervention as well as dramatizing the hazards of turning toward greater hazard. In such debates, the previous positions are revisited and resurrected to lay on the table argument, informed authority, and precedent. Thus, the 1932 debate between Keynes and Hayek has been invoked recently, in fact, not so much to recoup places of agreement or unique contributions to re-envisioning the relationship between theory and practice as to polarize positions and situate the dispute within a left-wing or right-wing policy presumption. Within such frameworks, advocates now jockey for advantage by declaring:

(1) they are faithful followers of the doctrines of Hayek or Keynes,

(2) that the times demand strict adherence to true principles, and

(3) that cataclysmic outcomes await those who hesitate or chose the other side.

Gerald P. O'Driscoll Jr., a former vice president of the Federal Reserve Bank of Dallas and now a senior fellow at the Cato Institute, for example, points to "newly discovered letters" from The Times of London (MacGregor et al., "Private Spending”, 1932a; Gregory et al., 1932) in order to insist that if Hayek were alive today, he would demand that efforts at economic stimulus be abandoned and that the global trading system be reinvigorated by removing all remaining barriers to open trade. Even if Keynes were right-a claim admitted only as a counterfactual in O’Driscoll's editorial-- President Obama, says O’Driscoll, is not following either Hayek or Keynes because he is "demonizing business and creating regime uncertainty through new programs and costly regulations," which engenders a loss of confidence not part of either economist's project. On the other side, Paul Krugman, Nobel Laureate and economics professor at Princeton, has reviewed the "dueling letters" on his New York Times blog. He describes Hayek's claim that barriers to trade and capital movement were preventing recovery as "crazy" (Krugman, 2010). Krugman credits Keynes with having worked out almost all of the policy implications of The General Theory of Employment, Interest, and Money (published in 1936) by 1932, including the insight that both higher private and higher public spending expand employment in a slump. Krugman expresses regrets that a debate concluded is now being restaged.

We rejoin the debate between Hayek and Keynes, in part, to repair the binaries and polarities within which theorist has been cast by subsequent, polarized advocates of political economy. Within the larger contexts of their 1932 exchange, it turns out that Hayek is not a right-wing hero, any more than Keynes is a liberal managerial technician, removed from 
institutional constraints. Of course, economic theories can be read as a linear, progressive history of ideas. The situated qualities of argument are shaved away to leave the form of causal order in defining the basic, underlying principles of exchange. Such foundational work yields the promise of control--with ever greater degrees of power and reliabilityover markets and economic activity. Older views, inadequate to the broadening scope and narrowing precision of advancing theories, then, can be distilled to essence, particulars of context abandoned, and the specifics of argument consigned to the waste bin of history without loss. That is not, however, our reading strategy. We prefer to begin from the assumption that humans are self-constituting, and therefore economic theories can be re-popularized in a new age, and theoretical controversies can reappear. Different groups engage in appropriation or critique of those theories to gain argumentative standing and to strive for advantage. Critical engagement with situated texts is necessary to repair

appropriations of theory that unproductively curtail and limit the range of rhetorical aspects of theoretical disputes that respond to mixed and selfconstituting rather than essentialized and purified polarizations to claim public authority.

In this respect our aim is to extend other work of our colleagues that appears in this edition of the POROI journal. McCloskey and Lyne in their dialogue, and in their articles Ramos and Mirowski, as well as Depew, look at the rhetoricity of practices internal to the texts of social discourse. Each of our strategies follows a parallel track, developing positions, putting them in rhetorical terms, and creating new directions for belief and action. In the following review, we set the context for the articulation of economic debate in the uncertain transitional political economy during a turn from the market values from war time savings to domestic consumption; then, explicate the positions of Keynes and Hayek within this uncertain context of transition during the Depression; and, finally reconstruct and recover Hayek's position in relation to contemporary debates in the articulation of economic value. The close reading of the 1932 debate in context thus enables a broader recovery of Hayek's theories of economy in relation to contemporary practice. To be sure, oppositional grounds remain at the level of the means of intervention and the sources of uncertainty between Hayek and Keyes; however, there is sufficient common grounds between these modern economists to offer grounds for a consensus on crucial public policyregulating practice and to resist polarization in the interests of partisan power and expert authority.

\section{Setting the Rhetorical Stage for the 1932 Keynes - Hayek Letter Exchange}

Seven years before his date of destiny with Adolf Hitler and before he declared "peace in our time," Neville Chamberlain assumed the post of Chancellor of the Exchequer when the Conservative coalition ousted the Labor Party from voting control in Parliament. The UK had experienced hard economic times for several years, and the members of the Labor Party Cabinet were unable to articulate a theory and practical plan for 
reversing the downturn. The victorious Conservative coalition insisted that the first step was to put in place new fiscal austerity measures. The supplementary budget proposed on September 10, 1931 combined a 35 million pound cut in unemployment benefits and public sector wages, a refinancing of 22 million pounds of War Loans to take advantage of lower interest rates, and a tax increase of 40 million pounds. Chamberlain worked to push the proposal through the political process, and announced on April 19, 1932 that the budget had been balanced with a small surplus (Morton, 1943, 70-71). On the basis of this accomplishment, Time Magazine considered Chamberlain ("Britain's Strong Man") for Man of the Year 1932, although the award eluded him until 1938. But Chamberlain recognized that the tax increase was alienating tax-paying supporters of the Party and decided to leave open some hope for future tax relief connected to further budget cuts. In a May 10, 1932 speech at the Bankers' Dinner he observed that taxpayers were "crying out for still further efforts at economy," but that "real effective relief to the taxpayer" would require a more comprehensive debt reduction pact than was currently being contemplated (Morton, 1943, 71). During the same period, however, Chamberlain also introduced a 10\% general tariff in an effort to rectify an adverse balance of trade by diminishing imports and encouraging domestic manufactures, which became effective on March 1.

There is support, then, for the belief that Chamberlain carried out an economic policy during a world recession that placed the burden of adjustment primarily upon ordinary UK citizens by reducing public employment and welfare payments, decreasing the interest rate on war bonds, and increasing taxes and the prices of imported goods. How was this onerous set of impositions justified? An examination of Chamberlain's exemplary June 30 address to the House of Commons on war bond conversion, which appears to have stimulated the series of London Times letters to the editor beginning on July 5 and so leading to the Keynes-Hayek exchange in October, suggests that the onerous was grounded in appeals to the honorable. Chamberlain appeals, for example, to the "good sense and patriotism" of those holding war bonds. The good sense consisted of an understanding that the high rate of interest (5\%) payable on the bonds was greater than comparable rates of return on other securities and that these high-interest war bonds depressed both competing investments and trade. There was also a negative inducement to good sense. The government would find other ways to extinguish the debt if the bondholders did not agree to the conversion. The invocation of patriotic duty was an extension of government appeals during wartime encouraging British citizens to put their surplus funds in war bonds so that the government could commandeer resources needed for the war effort. In the current situation, "economy is an urgent matter, and this scheme, effecting so great a reduction in our interest charges, is an essential element in any economy proposals" (Chamberlain, 1932b). Britain's budget and trade problems, then, justified wartime measures and, in particular, called upon consumers to tighten their belts and donate the surplus to the government at lower rates. The appeal was effective; 92\% of war bondholders accepted the lower interest rates (although even the new interest rate of 3.5\% was better than what the average investor could obtain elsewhere) (Leaviss, 2010). 
Chamberlain's rhetorical strategy seemed to participate in a productive conflation of "economy" as a financial entity or process with "economy" conceived as concern for or means to reducing government expenditure or "economizing." In a July 11 appearance before the House of Commons Chamberlain attacked an opponent on the "question of economy":

I think, however, that the purpose of to-day's discussion was understood to revolve around the question of economy. The hon. and learned Member for East Bristol said that economy was the reverse of the right policy for the Government of this country, from which I conclude that the converse is true, and that in his opinion the right policy for this country is one of extravagance. (Chamberlain, 1932a).

From this perspective, the role of political economists must be to preserve the economy by economizing on government expenditures. Austerity and prosperity are coincident.

The financial austerity program was accompanied by continuation of the monetary contraction the UK had experienced while the government preserved the gold standard during the economically difficult period between 1929 and 1931. In spite of the UK government's decision to abandon the gold standard in mid-1931, the earning assets of London clearing banks decreased by an additional 3\% between September 1931 and May 1932 (Morton, 1943, 47). They did so perhaps in part because in response to the decision to abandon the gold standard the Bank of England raised the discount rate from 4.5 to $6 \%$ out of a fear of inflation. On February 18, the Bank began to reduce the discount rate, eventually reaching $2 \%$ on June 30 . But by then the short-term economic damage had been done. Furthermore, Chamberlain made a decision to begin a policy of "quantitative easing" in May as a way to create "cheap money" that would be necessary to help finance the war bond conversion program. But "quantitative easing" did not guarantee increased business investment because during the war bond refinancing period (June to September 1932) private investors were prohibited from issuing new securities. Investment was further inhibited by the uncertainty as to whether war bond refinancing would be sufficient to achieve its goals (Morton, 1943, 250-251). Thus, although UK banks began to buy government securities at a rapid rate thereafter and liquidity increased substantially in 1933, the combination of fiscal austerity and discount rate increases in mid-1932 seemed to promise yet more deflation.

It was against this background that on July 5, 1932, The Times of London published a letter to the editor signed by 41 prominent economics professors across the UK, including Keynes. The letter blamed "the great fall in wholesale prices" since 1930 for the most serious evil of the economic crisis. Although some prices can adjust downward as well as upward in response to supply and demand changes, it was claimed, other prices were "relatively inflexible," thereby creating "serious maladjustments throughout the economic system." Those prices that are adjustable, then, need to be raised to where they were before the crisis 
began. This could be done by private spending, monetary easing, tax rebates, and public investment.

The choice to emphasize private spending on the list of actions needed to achieve re-inflation was part of the letter's effort to reverse the equation of private austerity with the appeal to patriotism that had worked so well for Chamberlain. Under the heading "Fresh Money for Spending," the letter exhorted private individuals and institutions to assist "by spending money according to their capacity." The sentence following this passage is explicit about how presumptions about capacity to spend should be set: "In cases of doubt, the patriotic motive should weigh on the side of expenditures rather than economy." Finally, the government should alleviate the sense of uncertainty that was provoking public fears of inflation by declaring its commitment to this new policy in advance, and not use re-inflation as an excuse to engage in competitive devaluation of the pound, which would worsen the world situation (Allen, et al., 1932).

More letters published in The Times of London on July 7, 1932 took a different tack. They recognized and called out the effort to change the existing presumption in favor of economy in the sense of economizing. They mustered once more the claims about the effects of the Great War on postwar British economic resources, adding to that patriotic invocation the uncertainty about the ultimate status of British war debt to the United States, which had been suspended since 1931. The public must not "relax its sense of corporate gravity and launch out on a course of what, outside of seminars for optimistic undergraduates who know the otherworldliness of their teachers, may be taken for an authorized and altogether indulgence of their private tastes and capacity for wheedling loans at interest out of bank managers" (Newbold, 1932). Another letter insisted that no "representative body of opinion" would respect reinflation in light of the psychological danger of "fear and uncertainty always attending suggestions of inflation" (Coxall, 1932). These opinions, insulting as they might seem to prominent economists, were in line with the official editorial position of The Times of London, which continued to publish essays in support of "strict economy" and "wise spending" over the next few months.

Nevertheless, the notion that it might actually be the patriotic duty of UK citizens to spend rather than to hoard money or return funds to the government had been planted, and its seeds sprouted further missives at the conclusion of the War Loan conversion program in early October. A World War I RAF pilot, P. W. Petter, wrote a letter that appeared on October 7 on how the British government's success in the war loan conversion program constituted a justification for a national effort to increase private spending, with possible supplementation from public expenditure (Petter, 1932). C. H. St. John Hornby, a prominent private book publisher, placed a letter on October 11 that agreed with Petter that "wise spending" by individuals is that which employs as many people as possible and called upon economists to draw up a scheme which would make such a determination. Hornby makes reference to the persuasive effect that the previous phrase regime of "economy" had upon private spending: 
So much has been written and spoken about economy during the past 12 months that most people seem to be imbued with the idea that they are performing a public service by buttoning up their pockets, whether they have money to spend or not ... Words are dangerous things, and not the least dangerous is the word "economy" in the mouths of those who do not realize its full implications (Hornby, 1932).

After citing the July 5 letter, which he did not feel safe to sign, Oxford professor of political economy D. H. Macgregor continued that letter's argument in an October 13 submission by co-opting the force of the word "economy" by differentiating its meaning from "parcimony" [sic] to associate economy with the project of re-inflation, by means in part of public expenditures:

Economy has two opposite, waste and parcimony [sic]. If we reduce waste where we can it should be to free resources for remunerative spending. This applies to both public and private enterprise. .. Just because depression means uncertainty, the private buyer is disposed to save beyond normal. This special parcimony, with its cumulative results, needs a special counterpoise. Otherwise we shall spend our substance in riotous saving. We cannot afford to wait for the boll weevil or a drought to rescue prices (Macgregor, 1932).

William Dampier, British scientist and first secretary to the UK Agricultural Research Council, theorized the rules of "economical" private spending and connected them to re-inflation:

Thus I conclude, first, that the nation and the individual should, now as always, avoid waste, get the best value for their money, and save, but only save as far as they can find remunerative new investments in public works or private enterprise. Secondly, I think that, as long as we are in danger of a further fall in the price level of primary commodities-an increase in the value of money-it is dangerous to carry saving beyond that amount (Dampier, 1932).

All of these letters to The Times of London preceded the beginning of what other scholars have identified as the "Keynes-Hayek debate of 1932." As we discuss below, they set the stage and the parameters for that debate and the theoretical work that followed. By distancing the experiences of citizens in the economic conditions of the 1930s from those occasioned by the Great War, these letters initiated the dissociation of patriotism from private parsimony. Moreover, by playing on the denotations and connotations of the word "economy," they reversed the previously productive equation of parsimony with economy by recognizing the equal accuracy of conditioning the value of saving money on the successful functioning of the "economy" as a whole. By reframing the problem of "uncertainty" from one that justified private hoarding to one that entailed countervailing risks of over- and under-spending to be evaluated and 
weighed through public argument they created an opportunity for Keynes and Hayek to connect their theorizing activities to a live public controversy. Nevertheless, the arguments articulated in these letters were linked to a particular proposal of "price re-inflation," which potentially limited the generalizability of the economic explanations and justifications to other situations. The subsequent contributions of Keynes and his colleagues and Hayek and his colleagues opened the horizon for theorizing the implications of economic uncertainty on consumption, saving, investment, and supply and demand for money in ways that could be cited and applied in future controversies.

\section{The Keynes-Hayek Debate in The Times of London}

At the time of the exchange of letters, neither Hayek nor Keynes had published the works of economic theory for which they would become most famous. Hayek had just arrived in London from Austria in 1931, taking an academic position at the London School of Economics. He had published Monetary Theory and the Trade Cycle and Prices and Production, which began the development of his monetary theory of business cycles. Keynes, in his academic position at Cambridge and as an informal governmental advisor, had published a series of pamphlets on specific economic issues, his Treatise on Probability, his Treatise on Money, and a volume of policy essays entitled Essays in Persuasion. The Treatise on Money (1930) was the longest work of the group and most directly related to political economy. It set out Keynes's early views on the differences in motivation between savings and investment which prevents their automatic equalization in a credit money economy, as well as his attempt to formalize in a set of equations how an economy moves from one price level to another (Skidelsky, 2010, 70-72). Hayek had critiqued the Treatise on Money in an August 1931 article in the journal Economica, to which Keynes replied that the Treatise no longer represented his economic views. At about the same time, Keynes changed the title of his October 1932 Cambridge lecture series from "The Pure Theory of Money," the subtitle of the first volume of the Treatise, to "The Monetary Theory of Production" (Skidelsky, 2010, 83).

Keynes was not the chief signatory to the letter that initiated the debate on October 17. Rather, it was D. H. Macgregor, who had submitted the October 13 letter that connected the October dispute over private and public spending to the July 5 letter signed by 41 economists. The style of much of the October 13 letter seems to reflect MacGregor's concerns and rhetorical strategy, but the latter half includes a brief unfolding of Keynes' convoluted theory of differential motives for savings and investment and connects it to the demand for money.

The letter's first paragraph accepts Hornby's invitation to develop a perspective on the problem of private spending, and claims that this view is one with which most British economists would not disagree. Then the text moves to the issue of patriotism and the comparison of the exigencies of the War economy with the Depression economy. "In the period of the War it was a patriotic duty for private citizens to cut their expenditure on the purchase of consumable goods and services to the limit of their 
power" (MacGregor et al., 1932a). But the resources freed up were used by the government to conduct war. "At the present time, the conditions are entirely different” (MacGregor et al., 1932a). The retained resources are not used for war, or, quite possibly, for any other productive purpose. What characterizes the depression economy is paralyzing uncertainty, or a lack of confidence, that discourages people both from buying securities and from investing borrowed money in factories and machinery to make consumer.

In attempting to explain why demand for consumer goods deserves such a central role in the determination of national income, the letter draws upon Keynes' differential motivation position. It figures demand for consumer goods as the starting point for decisions by the consumers to save money that can be used for investment in future production (MacGregor et al., 1932a). This reverses the traditional ordering principle of Say's Law, which posits that supply calls forth its own demand, by imagining that consumers plan for their own future consumption by directly or indirectly making funds available to producers for capital purchases. An increase in personal savings through "bank balances or even in the purchase of existing securities," then, would be associated with a decreased desire or propensity to consume in the future. Thus, private "economy," or hoarding of money, "cuts down the national income by nearly as much as it cuts down consumption" because "capital expenditures decisions are counting on the expected future demand" (MacGregor et al., 1932a). Moreover, the complex reasons why people hoard money may become disconnected from the basic desire to consume. By moving in the direction of motives that are a response to declining incomes, people who decide to hoard can cause an initial downturn to snowball. This outcome returns the argument to its rhetorical premise: “...to spend less money than we should like to do is not patriotic" (Macgregor et al., 1932a). To the degree that Chamberlain's austerity policies are encouraging this kind of individual behavior by higher taxes and tariffs, lower interest rates on war bonds, and reduced expenditures on social welfare, it contributes to unpatriotic action that threatens future growth.

Because public goods are subject to similar consumption decisions as are private goods, this line of reasoning about the misguided nature of hoarding applies to decisions of local governments to refrain from providing essential services such as swimming pools, libraries, and museums. "They will be 'martyrs by mistake,' and, in their martyrdom, will be injuring others as well as themselves. Through their misdirected good will the mounting wave of unemployment will be lifted still higher" (Macgregor et al., 1932b). Thus, implicitly, localities can offset the effects of economic distress on private spending by supplementing it with public expenditures that lead to a consumable good or service.

The reply to this letter that appeared two days later in the London Times of October 19 placed Hayek's signature in a position second to that of T. E. Gregory, the governor of the London School of Economics, but above that of Arnold Plant and Lionel Robbins. Yet the organization of the letter suggests Hayek's substantial involvement in its composition, and a continuation of his critique of Keynes' theories in the Treatise on 
Money. Like a debater who wants to make the areas of difference stand out in a short presentation, the text divides the question into three major issues and purports to set forth the precise points of disagreement between Hayek and colleagues and Keynes and his associates. The first issue involves an effort to preempt the differentiation of economy from parsimony that fueled criticism of the British government's encouragement of reduced consumption. The text pledges agreement with the view that hoarding money is deflationary, and deflation is not desirable in itself.

The statement of the second issue alleges a disagreement with Keynes and associates about the desirability of focusing upon consumption spending rather than on "real investment." As noted previously, the October 17 letter classified investment in existing securities as wasted social expenditure because there would be no guarantee that the proceeds would not end up in the pockets of brokers and sellers rather than used for production of new goods. The letter links the uncertainty and loss of confidence in financial circles resulting from the declining popularity of existing securities to the unlikelihood of additional instruments being issued. "A rise in the value of old securities is an indispensable preliminary to the flotation of new issues" (Gregory et al., 1932). Even suggesting the possibility that individual investors should abandon the stock market might hurt financial confidence under current circumstances. "It is perilous in the extreme to say anything which may still further weaken the habit of private saving" (Gregory et al., 1932).

The final issue concerns a difference of opinion about the relative investment capabilities of public and private agencies. Here the signatories take advantage of the presumption given by many readers of The Times of London to the soundness and impartiality of its editorial opinions. On Monday, October 17, the editorial on "Economy and Unemployment" restated the newspaper's preference for lean government programs. It indicts public employment on the grounds that the jobs are too costly, and that those paying taxes for them will become unemployed because higher taxes will discourage business and consumption. While ostensibly agreeing with the Times editorial position, the October 19 letter transforms the question of public means of promoting employment into an assertion about the competency of public agencies to make any investments. "We are of the opinion that many of the troubles of the world at the present time are due to imprudent borrowing and spending on the part of the public authorities. We do not desire to see a renewal of such practices" (Gregory et al., 1932). Public debt is asserted to inhibit adjustment to adverse economic conditions more than private debt and to crowd out private borrowing. Thus any public investment that requires bonding must be rejected, even if "people 'feel they want' such amenities." Governments also have the power to remove impediments to trade and capital investments. They should do so if they hope for economic revival (Gregory et al., 1932).

Those who have chronicled the Hayek-Keynes exchange in recent times for its resonances with the current economic crisis have ignored the publication of a third letter to The Times of London by the Keynes group on October 21. This letter responds most directly to a letter published on 
October 18 by Ernest Benn, a British publisher, writer, and political publicist, and W. W. Paine, the general manager of Lloyds Bank, Ltd. Benn, at least, gave his critics reasons to suspect that his economic beliefs were carefully tailored to his current occupation. He had found justification for state intervention when employed in the Ministry of Munitions and Reconstruction, but supported "undiluted laissez faire" when he started his publishing firm after the Great War (Abel, 1960, 11). The letter from Benn and Paine claims to agree that people have a duty to spend, but not on bonding community facilities like swimming pools, libraries, and museums because they draw resources that would employ more people and impose a debt burden on the population (Benn \& Paine, 1932).

Yet the Keynes group letter also has something to say to the Hayek group's claim about the "crowding-out" effect of public investment on alternative forms of employment. Whether that claim is grounded in assumed limitations on an available pool of money or on a supply of physical resources, it is "an illusion," as Adam Smith recognized long ago. Most of the value in a product, says the text, is found in the "brains, hands, and capital equipment of the country" (Macgregor et al., 1932b). These are not finite in the same sense that money or physical resource are because they will not be used in the absence of a deliberate decision to produce. "They simply do not come into existence." Under the uncertainties created by the current economic recession, capital investment in and production of capital goods will not trade off with similar activities for consumption goods, but will simply not be undertaken at all, idling both labor and capital (Macgregor et al., 1932b). The equation of capital and consumption in relation to production is indicated by the ease within which the letter adopts and adapts the term "capital goods" from neoclassical economics to reinforce the centrality of consumption practices. It does so through its identification of capital as a "good."

\section{Recovering Hayek for Contemporary Practice}

The Hayek-Keynes debate has been recollected and deployed for partisan support or opposition. The uses of Keynes and Hayek as oppositional strategy thus are adduced to bear upon the contemporary economic crisis of the United States. At present, the Obama Administration is said to follow Keynesian interventionary policy by using fiscal and monetary tools to stimulate spending and investment. The critical ground opposing Obama appears to be drawn from Hayek (particularly as extended by Milton Friedman). The Federal Reserve is pursuing a policy of Quantitative Easing and expanding the money supply to avoid a deflationary spiral and stagnation similar to the Japanese economy, since its bubble burst in 1997. The reduction of the value of the dollar raises prospects of inflation, when demand resumes. Inflation is one way to adjust great debt burdens, paying national and international creditors back with cheaper currency. Inflation sometimes transitions to hyperinflation, a spiral of rising price expectations creates incentives for hoarding and price hiking in anticipation that dollars received today will 
be worth less tomorrow. High interest rates are the only way to disrupt such a spiral. So, as Ebenstein argues,

[i]t is likely that at some point the Fed will raise interest rates and curtail existing measures to increase liquidity in financial institutions. Or it may allow prices to inflate. The United States could be in for a double-dip recession in which economic activity responds to the unprecedented fiscal and monetary stimulus but then hits a wall as interest rates and prices rise. Hayek's adversary, Keynes, recommended fiscal policy rather than monetary policy as the way to steer an economy, and this seems to be the Obama administration's intention (Ebenstein, 2009) .

In Europe, an era of austerity has descended in order for governments to create manoeuvring room for physical policy, while at the G20 summit, nations over split over United States' cavalier treatment of the dollar's exchange value. Conservatives would limit government intervention into any economic downturn and Hayek is sited as a source that justifies such restraint; however, while Hayek was skeptical about central planning generally, careful inspection of his theory in relation to the articulation of constitutive practices theory nevertheless provides ample grounds for boundary setting and regulation of capital industries-a quite different matter.

Society for Hayek is formed from a multitude of individuals who succeed "when their activities are mutually adjusted to one another" (Hayek, 1981). Adjustment works because people " in society can successfully pursue their ends because they know what to expect from their fellows" (Hayek, 1981). Individuals in society

"can successfully pursue their ends because they know what to expect from their fellows. Their relations, in other words, show a certain order. How such an order of the multifarious activities of millions of men [and women] is produced or can be achieved is the central problem of social theory and social policy" (Hayek, 1981)

The central theoretical question, thus, is how a social order made up of "the multifarious activities of millions of men is produced or can be achieved" (Hayek, 1981). Reciprocal expectations create an on-going, experimental field of activities, we think, where the final product is the collectively endowed practices of complex market experiments. This premise celebrates the productive form of knowledge generation while at the same time restricting the hubris of elite intervention. Hayek draws support from this view from homologous arguments to human intervention into nature:

We could never produce a crystal by directly placing the individual molecules from which it is built up. But we can create the conditions under which such a crystal will form itself. If for that purpose we make use of known forces, we can, however, not determine the position an individual molecule will occupy within a crystal, or even the size or position of the several crystals.

Similarly, we can create the conditions under which a biological 
organism will grow and develop. But all we can do is create conditions favorable to that growth, and we are able to determine the resulting shape and structure only within narrow limits. The same applies to spontaneous social orders (Hayek, 1981).

The idea of spontaneous social order-in between design and human invention--slips Hayek into alignment with Milton Friedman and freemarket ideologists from Reagan-Thatcher onward. As Beichman contends: "because the planner cannot know relative costs and scarcities, the planned economy will in fact be chaotic and vastly wasteful." Particularly, his early Cold War text, Road to Serfdom, is celebrated among conservatives as "one of the foundation texts" for the movement. Further, "the collapse of communism and the end of the Cold War have proven the vitality and prosperity of economic freedom. Markets are the norm in most countries," (Beichman, 2000, 16) Beichman concludes. John Gray confirms the success of the Nobel Laureate: "it turned out Hayek had been right all along, namely, that socialist central planning would not only fail but that its failure would, for the sake of regime survival, introduce dictatorship" (Beichman, 2000 [quoting Gray], 16).

The epistemic basis for Hayek was based less upon a fully articulated conservative ideology than on a strong presumption against restrictions of freedom based upon abstract, extrapolated rules. The views are grounded in Karl Popper's modernist, falsifiable thinking. Indeed, "Hayek's entire approach to economics, in line with the Austrian School, emphasized the limited nature of knowledge" (Ross, 2004).

Yet Hayek does not ground market success and economic practice in natural law theories of maximizing economic freedom at the expense of demanding universal restrictions against state intervention; rather, he posits "slow evolution" as a feature of evolving economic conditions. Markets "must continuously form and reform themselves," he writes, "where only the conditions conducive to their constant reconstitution have been shaped by evolution. The genetic and the functional aspects can never be fully separated" (Hayek, 1981). The experimental quality of selfreformation sustains Hayek's well-known animus against central planning, but it does not rule out the need for timely intervention on the part of the state when the self-adjusting processes of experimentation fail. What kind and upon what grounds intervention is justified needs to be developed from the Austrian's views on the outer-boundaries of practice.

The evolutionary thrust for markets occurs in rule following. Rules may be implicit to a practice that everyone pursues, but no one is forced to think about, why individual pursuits produce a sustainable and successful common system is less important than the deployment and use of these norms and practices of deliberated conduct. Rules form in the habits of individuals and collectives before reaching the stage of linguistic articulation--when complexity yields tensions among common forms of imitation, convention, and strategic manipulation. In sophisticated markets, issues form over basic questions. As Hayek observes,

some such common rules the individuals will follow merely because of the similarity of their environment, or, rather, because of the similar manner in which this environment reflects itself in 
their minds. Others they will all follow spontaneously because they are part of the common cultural tradition of their society. But there are still others which it is necessary that they be made to obey, since it would be in the interest of each individual to disregard them, though the overall order will be formed only if the rule is generally obeyed (Hayek, 1981)

At this outer boundary, common law is the preferred vehicle of offsetting strategic manipulation because of its slow, piece by piece testing over time. Hayek believes that nations that govern economic exchange through common law rather than civil law are more successful economically.

The reasons rules emerge from practice is that knowledge within a market order is disbursed and distributed. As the Austrian economist writes,

the knowledge of the circumstances of which we must make use never exists in concentrated or integrated form but solely as the dispersed bits of incomplete and frequently contradictory knowledge which all the separate individuals possess (Hayek, 1945, 519)

Nevertheless, market agents are accorded a common sense that adjusts prices to value with speed and efficiency to circumstances. A growing abundance decreases price because more goods are to be found as available; a growing scarcity increases price because fewer goods are available. Thus, individual judgments reflect through combination the price which itself functions as a signal of rising or decreasing availability. Thus, even though "each entrepreneur operations within the bounds of his unique understanding of a particular 'locality', price signals encourage apparently independent entrepreneurial activities to become harmonised" (Steele, 2001, 14).

The epistemic assumption is drawn from the classical distinction between ratio cognoscendi and ratio essendi, that is knowledge provided by a sign and knowledge of the cause of the facts at hand. The capacity of a rational economic actor is limited by access, constrained by selection, and narrowed by timeliness. Entrepreneurs do not need theoretical knowledge to explain why a certain trajectory of choices is beginning to succeed and a previous set no longer works. Rather, economic knowledge is base upon appraisal of accumulating and converging signs in anticipation of a turn in the short and in the long terms. Such situated practices of knowledge are classically rhetorical, of course; in situations inviting deliberation leading to judgment and action, rhetoric is the art of marshaling timely reasons that critical appraise, properly motivate, and accord right standing in the choices at hand. Prudence is its virtue, contingency its limits, and an effectively choosing society its outcome. In this regard, Hayek's knowledge agent acting as entrepreneur is in line with classic Aristotelian rhetoric.

Modern theory offers altogether different opportunities and constraints for theory and practice. Theorization is the lynchpin of macro economic thinking that reads causes of economic behavior from 
"aggregate" data. Aggregate data are signals that are displayed over time and correlated to suggest economic success and failure in terms of meeting, exceeding or falling short of expectations. The analysis of aggregates through economic formula yields knowledge of cause and effects unavailable to entrepreneurs seated in their situated choices of how to read behavior, set expectations, and decide. Aggregates obscure more than they reveal, however, because factors composing the aggregates may wash out creating the appearance of an unchanged trend; but changes in make-up may signal turns that are building to threshold levels, with unexpected changes startling private and public planners alike who deploy aggregates to construct continuity of past into future. Useful knowledge needed to negotiate contingent circumstances "never exists in concentrated or integrated form but solely as the dispersed bits of incomplete and frequently contradictory knowledge which all the separate individuals possess" (Hayek, 1945, 519). Rhetorical weight then is constituted in the subjective impressions of the relevance, trustworthiness, and inter-reliability of the fragments. The rooting of judgment in singular cognitive translation of sense impressions has positioned Hayek as a champion of conservative individualism. For Keynes these sense impressions are driven by "animal spirits" that are a feature of the herd, released from the caution of the day and hunting in the wiles of darkness. Neither Hayek nor Keynes find that individual entrepreneurs, investors, or consumers carry out their activities with complete, exhaustive information; they disagree as to where the knowledge may be found, in the welter of practices meshing together rules for purposes of advantage or in the rules at play that can be deduced from outcomes.

What is removed from sight in the positioning Hayek against Keynes is the social nature of learning which extends beyond the isolated individual at point of judgment to the formation of common sense over and against theory. Hayek concludes,

We need to remember only how much we have to learn in any occupation after we have completed our theoretical training, how big a part of our working life we spend learning particular jobs, and how valuable an asset in all walks of life is knowledge of people, of local conditions, and of special circumstances (Hayek, 1945, 522)

What is key to economic activity is not only making up expectations that are prudent but also reading them against expectations of others upon whose satisfactions work and reward depend. So much does he depend upon this learning, that self-positioning occurs best in a world unquestioned and taken for granted. Prices send signals. Price system itself is

a kind of machinery for registering change, or a system of telecommunications which enables individual producers to watch merely the movement of a few pointers, as an engineer might watch the hands of a few dials, in order to adjust their activities to changes of which they may never know more than is reflected in the price movement (Hayek, 1937) 
One can build upon habits through judgment by following the successful habits of practices and institutions that have built up over time and furnish foundations. Those who cultivate the ability to critically appraise certain conditions or circumstances inviting intervention, even though tested by competition, will over the long run win. Yet, the very taken-forgrantedness of reading signals as indicators presupposes a social world that underwrites the communication practices of the markets.

The Austrian view has a social, rather than purely individualist basis, because it borrows its basic ideas of practical reason from Aristotle's understanding of the virtues demanded by successfully managing household economy-a term broader than individual family or city-state circumstances. Catallaxy--the order brought about by the mutual adjustment of many individual economies in a market--is at the roots of a knowledge economy where the grounds of prudence are woven into the cultures of practices, as the community addresses-presents, evaluates and judges--special cases with particular knowledge from a variety of interested sources. Hayek finds Aristotle's Nicomachean Ethics compelling:

Nor is Prudence a knowledge of general principles only: it must also take account of particular facts, since it is concerned with action, and action deals with particular things. This is why men who are ignorant of general principles are sometimes more successful in action than others who know them: for instance, if a man knows that light meat is easily digested and therefore wholesome, but does not know what kinds of meat are light, he will not be so likely to restore you to health as a man who merely knows that chicken is wholesome; and in other matters men of experience are more successful than theorists. And Prudence is concerned with action, so one requires both forms of it, or indeed knowledge of particular facts even more than knowledge of general principles. Though here too there must be some supreme directing faculty (Aristotle, 1141b7) (Hayek, 1945)

Ratio essendi in situations requiring action trumps ratio cognoscendi, which is powerless. Note though that the virtuous deliberations are not solitary; rather, Aristotle's rhetoric is a practical art, too, where the double-sided quality of signs point in conflicting directions and a practical art is necessary to sort, read, arrange, stylize, remember and order the common experiences through adjusting symbols in the interests of restraining or releasing action. Rhetoric offers an art of collaboration, not reducible to individual cognition. Trust in practical reasoning takes its turns on the requirements to build confidence in lending and investing, the very strategies that enable expanding market activities.

Capital investment carries forward classical epistemic traditions into modern thinking. Capital investment is based upon expectations truly successful for the longer-term anticipation of wealth generation and apparently successful with the short-term response to opportunity. As Steele explains:

capital investment permits 'roundabout' methods of production (for example, machines are produced in order that commodities 
can be produced; or land is drained in order that commodities may be grown). After a period of gestation, those capital investments yield earnings from the sale of the commodities whose production they make possible. 'Shallow' investments bring commodities to the market relatively quickly, but 'deep' (or, in modern terminology, highly capital-intensive) investments are technically (though not necessarily economically) more productive (Steele, 2001, 31).

If capital is directed through planning, the policy will distort the sorting process by which genuine opportunities will attract long-term investment. Short-term stimuli will systematically distort investment as risk takers adjust their standing to pay-offs made opportune by government stimulus, thereby making "real recovery" less likely or longer to achieve. These views underscored Hayek's view of economic recession, which occurs

when an investment boom is sustained by easy credit, the implication is that investments are insufficiently covered by saving; consumption is too high and shortages will accumulate. A painful retrenchment is inevitable (Steele, 2001, 32)

It seems to us that state central planning is not the only source of systematically distorted communication. Rather, in the present recession, the state operated with large banks to enable a system underwritten by cronyism-reciprocal benefit of large institutions in the interest of power and profit at the expense of national and international investors. Conservative ideology was deployed as a universal to support the view that all state deregulation would result in more perfectly functioning free markets-removing protections against speculation that have been in effect since the last outrageous episode of the Great Depression. Yet, unlike the Depression the freed up market forces were backed by explicit and implicit government guarantees of a bailout, should their appetites get too large-a bailout at the expense of the taxpayers. This situation moved moral hazard to the realm of a social rather than individual problem. Moral hazard occurs when leverage is encouraged because there are only benefits to be had by risk taking because an exogenous agent has guaranteed to pick up losses. Moral hazard was a nineteenth century issue for the insurance industry. Underwriters worried that if an individual were insured to a high level, then the motive to exercise normal caution would be reduced. Insurance would create a moral hazard by motivating bad judgments in excessive risk-taking.

Hayek's thinking about distorting capital investment through systems of false signals inviting investment now can be extended to big banks whose derivatives are not regulated and so out of site of government, yet at the same time government has an implicit promise to provide rescue.

Two cases are relevant. First, Fannie Mae and Freddie Mac were started as government agencies, but had been privatized. Still their mortgage investment pools were attractive because as quasi-government agencies; they were backed by the US federal government. Second, derivatives are volatile new instruments of financial engineering. Leveraging investments may make the formulas volatile. In 1997, a Wall Street bank 
failure was mitigated by the action of the US federal government. In 2007, the added argument was "too big to fail," which assured investors of the likelihood of a bailout, especially after the consequences of the Lehman Brothers bankruptcy were demonstrated. The partnership between capital and government created moral hazards on a vast scale. Just as conservative advocates now blame Roosevelt for the length and breadth of the depression through interventionist fiscal and monetary policies, so they argue that current Keynesian interventions are failing-as predicted by Hayek. Meghnad Desai and Robert Skidelsky of the Manchester Guardian, for example, conclude of quantitative easing:

Wherever the money has gone, it is not into the real economy. A similar situation prevails in the US where, as Alan Greenspan pointed out in the Financial Times of 6 October, corporates are using the money supply to buy liquid assets rather than "real" investments. Consumers are also not spending but saving to deleverage, and even so consumer indebtedness is still dire. Much more deleveraging will have to be done before the negative wealth effect will vanish and spending resume. This is very much what Hayek's theory leads one to expect. The crisis, he says, occurs because there has been a long run of cheap credit resulting in malinvestments, like today's sub-prime mortgages. Expectations of lending banks change, we have a reversal of cheap credit and the boom collapses (Desai \& Skidelsky, 2010).

While the analogy appears strong, a jump to non-intervention into market activities remains unwarranted, precisely because the ideology of apparent deregulation set the grounds for a mixed government-private distortion of risk signals. Further, the articulation of change from war to peacetime economy does not speak to the habits of consumption and uncertainty that mark the tensions of a global economy. All analogies are limited, to be sure; however, what disciplinary purity and ideological polarization accomplish by perfecting difference is to conceal key common grounds useful for understanding economic theories and practices in emergence and for achieving an informed policy consensus.

\section{Conclusion: Then and Now}

A close reading of the actual exchange between the Keynes group and the Hayek group in the context of the letters in The Times of London that appeared before and concurrently with the exchange reveals that the positions developed, when appropriated by contemporary economists as clear and decisive arguments for or against practices like government stimulus or quantitative monetary easing, are considerably more ambiguous than claimed. First, both groups orient their position in opposition to the previously valued British figure of the patriotic citizen who either hoards cash or gives it up in the forms of taxes, tariffs, or reduced bond income because these actions are said to be in the public interest. Both see this figuration as an anachronistic extension of wartime attitudes that threatens economic instability by inducing deflationary 
spirals. This point of agreement is potentially devastating to contemporary proposals to cut government budgets by more than $50 \%$ in the interest of paying off national debts. Second, neither group is persuaded to endorse the position that minimizing government expenditures is always justified by the "principles of economy" that conflate the economic model of exchange processes with the pursuit of efficiency in resource use to create a "fundamental economic law." Both the Hayek and Keynes groups worry not about inefficiency per se, but instances where public authorities move outside their areas of competency to undertake projects that are not closely connected to encouraging either private consumption or investment. They do not participate in the broader presumption of "economy" and its radical opponents that government always or never wastes money, and thus refuses to grant or deny legitimacy to any particular activities. Finally, both groups recognize the inherent role of uncertainty in economic decision-making, and thus the need for deliberation, argument, and collective choice at various moments in economic life. Hayek does not think an economic system is an automatic decision making process. While they may differ strongly on the sources of uncertainty, both the Hayek group and the Keynes group preserve its contingent nature and constitutive force.

This finding corresponds to G. R. Steele's work in the interpretive history of economics as a discipline. Steele distinguishes the arguments of these modern economists from classical, natural law beginnings. "Since all human action is directed towards changing some future state, uncertainty must pervade the outcome of every action that resides within the context of other people's actions" (Steele, 2001, 162). The first order question of uncertainty, of course, belongs to the market situated entrepreneur who must decide whether to buy or sell, or to pay more or less for a good, with capital to be used now or saved for later, in anticipation of producing more goods or simply increasing expected yield through higher prices. The second order uncertainty extends to the investor who must decide whether to increase the levels of risk-taking or withdraw from market activity, to go with or against the general trends of the crowd, to continue or to cash in at every turn. Then too there is a third factor that produces a new level of uncertainty in the very act of trying to reduce it. Economists gather data and craft models, make predictions and explain past outcomes. Practical judgments and theoretical models together push a third level of uncertainty, both in the comparative merits of theory and the new techniques of financial engineering built and certified by major institutions and the state. It is for these reasons, all rooted in the probability revolution of late 19th and 20th century science, that neo-classical economics assumes an equilibrium which, in fact for Keynes and Hayek, markets struggle always to achieve and whose continuity always remains uncertain. Keynes and Hayek both remind us of the contingent qualities of market practices, investment strategies, and theoretical models and apparatuses. How issues of contingency are addressed defines generative rhetorics that influence the left and right politics of national governments that during times of crisis, in the Great Depression and in the current Great Recession, vary widely. A rhetorical approach to economics addresses through appreciation and critique the 
uncertainties constitutive of the times as well as the re-articulation of such moments when public values, theoretical models, and market practices are in change. Critical rhetoric work extends and complicatesrather than purifies and uses--economic debates. In the case of the 1932 debates, we find areas of possible agreements between theorists, even while leaving room for differences. Close, constructive textual readings are necessary to reconstruct contingencies, block conversion of articulated positions to universal theoretical principles, and recollect and reconstruct the fuller, informed range of discussion in the interests of competent public policy.

In the end, partisan and ideological uses of the Keynes-Hayek debate to fortify the case against state intervention allow market fraud to go unchecked. Free-market slogans legitimated a scheme by the state and banks to render liquid the American housing market, creating a new debtor class. In the last two years, 4 million Americans have been thrown out of their houses, a quarter of all home owners (19 million families) owe more on their homes than the market value, and credit card bankruptcy laws were revised in 2005 in anticipation of the unsustainability of the bubble. Hayek demanded the protection of common law against the planning of the state. In the recent debt bubble, the government's supposed commitment to free enterprise in fact engaged in a planning scheme that resulted in a massive transfer of wealth, a credit crunch, and a huge transfer of home ownership back to the banks. Systematically distorted communication transforms the taken-for-granted signal sending qualities of the market into lures, traps, and eventually triumphs of planned wealth shifts. The problem, of course, is that these are not sustainable and without Keynesian intervention the triumph may be so complete that recovery may be long in arriving. A complete rhetoric is brought into play only when ratio essendi links with a powerful, critical counterpart in ratio cognoscendi-the shared common grounds of contingent policy choice in a political economy.

\section{References}

Abel, Deryck. 1960. Ernest Benn: Counsel for Liberty. London: Benn.

Akerlof, George A. \& Robert J. Shiller. 2010. Animal Spirits: How Human Psychology Drives the Economy, and Why It Matters for Global Capitalism. Princeton, NJ: Princeton University Press.

Allen, W. M., et al. 1932. "Restoration of Prices: Fresh Money for Spending." The Times of London. Tuesday, Jul 05, 1932; p. 10; Issue 46177; col A.

Beichman, Arnold, 2000. "The Hubris of Reason.” The Washington Times. September 18, 2000. p. 16.

Benn, Ernest J. P. \& W. W. Paine. 1932. "Private And Public Spending: An Untenable Analogy.”The Times of London. Tuesday, Oct 18, 1932; pg. 10; Issue 46267; col D.

Chamberlain, Neville. 1932a. "Economic Situation." House of Commons Debate. 11 July 1932. vol 268 cc923-1047 923. 
http://hansard.millbanksystems.com/commons/1932/jul/11/econom ic-situation\#S5CVo268Po_19320711_HOC_275.

Chamberlain, Neville. 1932b. "Five Per Cent. War Loan Conversion." House of Commons Debate. 30 June 1932 vol 267 cc2121-8 2121. http://hansard.millbanksystems.com/ commons/1932/jun/30/mechamberlains-statement.

Chamberlain, Neville. 1932c. "Reparations and War Debts." House of Commons Debate. 14 December 1932. vol 273 cc353-486 353. http://hansard.millbanksystems.com/commons/1932/dec/14/repara tions-and-war-debts-1.

Coxall, William C. 1932 "Fresh Money For Spending Effect On The Pound Abroad." The Times of London. Thursday, Jul 07, 1932; pg. 10; Issue 46179; col A.

Dampier, William C. 1932. "Saving And Spending More Money In Free Circulation, Methods Of Adjusting Prices." The Times of London. Friday, Oct 14, 1932; p. 13; Issue 46264; col E. Letter to the Editor.

Desai, Meghnad \& Robert Skidelsky. 2010. "Beyond Keynes and Hayek." Guardian.co.uk, October 28, 2010. http://www.guardian.co.uk/commentisfree/2010/oct/28/hayekkeynes-third-fourth-way.

Ebenstein, Lanny. 2009. "The anti-Keynes: Friedrich Hayek sheds light on our economic troubles." National Review, February 23, 2009. http://goliath.ecnext.com/coms2/gi_0199-9934486/The-antiKeynes-Friedrich-Hayek.html.

Gregory, T. E. et al. 1932. "Spending And Saving: Public Works From Rates." The Times of London.Wednesday, Oct 19, 1932; pg. 10; Issue 46268; col A. Letter to the Editor.

Hayek, Friedrich A. 1937. "Economics and Knowledge." An Address Delivered before the London Economics Club 10 November 1936. Economica 4 (1937).

http://www.cooperativeindividualism.org/hayek_economicsandknow ledge.html.

Hayek, Friedrich A. 1963. "Kinds of Order in Society." New Individualist Review (Indianapolis: Liberty Fund, 1981). http://oll.libertyfund.org/index.php?option=com_content\&task=vie w \&id $=1269 \&$ Itemid $=280$..

---- 1945. "The Use of Knowledge in Society." American Economic Review 35.4: 519-30.

---- 1931. "Reflections on the Pure Theory of Money of Mr. J.M. Keynes." Economica 11 (1931). http://mises.org/daily/2474.

Hornby, C. H. St. John. 1932. "The Time to Spend: Which is the Wisest Way? An Invitation to the Economists. The Times of London. Tuesday, Oct 11, 1932; p. 15; Issue 46261; col E.

Krugman, Paul. 2010. "Keynes Versus Hayek, 1932." New York Times (Online Edition). July 9, 2010. 
http://krugman.blogs.nytimes.com/2010/o7/o9/keynes-versushayek-1932

Leaviss, Jim. 2010. "What happened the last time the UK defaulted?" Bond Vigilantes (blog). February 2, 2010.

http://www.bondvigilantes.co.uk/blog/2010/02/02/12651210600oo. html.

Macgregor, D. H. 1932. "The Time To Spend: Work For The Workless, A Kentish Scheme." The Times of London. Thursday, Oct 13, 1932; pg. 10; Issue 46263; col A. Letter to the Editor

Macgregor, D. H. et al. 1932a. "Private Spending Money For Productive Investment, A Comment By Economists.” The Times of London. Monday, Oct 17, 1932; pg. 13; Issue 46266; col E. Letter to the Editor.

1932b. "Spending And Saving What Are National Resources? The Economists' Reply. The Times of London. Friday, Oct 21, 1932; pg. 15; Issue 46270; col E. Letter to the Editor.

Morton, Walter A. 1943. British Finance 1930-1940. Madison, WI: University of Wisconsin Press.

Newbold, Walton. 1932. "Fresh Money For Spending Effect On The Pound Abroad." The Times of London. Thursday, Jul 07, 1932; pg. 10; Issue 46179; col A.

O’Driscoll, Gerard P., Jr. 2010. "Keynes vs. Hayek: The Great Debate Continues.” Wall Street Journal July 7, 2010. http://online.wsj.com/article/SB100014240527487047384 04575347300609199056.html ?mod=googlenews_wsj.

Petter, P. W. 1932. "The Time to Spend." The Times of London. Friday, Oct 07, 1932; p. 13; Issue 46258; col E. Letter to the Editor.

Rizzo, Mario. 2009. "Keynes versus Hayek: A Rerun of the 1930s.” Think Markets, June 17, 2009.

http://thinkmarkets.wordpress.com/2009/o6/17/keynes-versushayek-a-rerun-of-the-1930s.

Ross, Kelley L. 2004. "Friedrich A. Hayek (1899-1992)." http://www.friesian.com/hayek.htm.

Skidelsky, Robert. 2010. Keynes: A Very Short Introduction. New York: Oxford University Press.

Steele. G. R. 2001. Keynes and Hayek: The Money Economy. London: Routledge.

Time Magazine Editors. 1933. "National Affairs: Man of the Year, 1932." Time, January 2, 1933. http://www.time.com/time/ magazine/article/o,9171,847107,0o.html.

The Times of London. 1932. "Economy and Unemployment." The Times of London. Monday, Oct 17, 1932; p. 13; Issue 46266; col B. Editorial/Leader. 